RESEARCH ARTICLE

\title{
Characterization of structural properties of fungal-bacterial biofilms by Fourier Transform Infrared Spectroscopy
}

\author{
I. D. Singhalage ${ }^{1,3,4}$, G. Seneviratne ${ }^{1}$, H. M. S. P. Madawala ${ }^{2}$ and I. S. Manawasinghe ${ }^{1}$ \\ ${ }^{1}$ Microbial Biotechnology Unit, National Institute of Fundamental Studies, Kandy, Sri Lanka \\ ${ }^{2}$ Department of Botany, Faculty of Science, University of Peradeniya, Peradeniya, Sri Lanka \\ ${ }^{3}$ Department of Science and Technology, Faculty of Science and Technology, Uva Wellassa University of Sri Lanka, \\ Badulla, Sri Lanka \\ ${ }^{4}$ Postgraduate Institute of Science, University of Peradeniya, Peradeniya, Sri Lanka
}

Received:22/09/2017; Accepted:21/02/2018

\begin{abstract}
Investigating the structural properties of biofilms is important as they undergo profound changes in their genetic and cellular make up once planktonic cells are converted to biofilm communities. Present study focused on examining the structural attributes of fungal-bacterial biofilms (FBBs), a novel introduction to biotechnological applications, in comparison to bacterial (BBs) and fungal (FBs) biofilms. Enterobacter sp. and Aspergillus sp. were used as the bacterial and fungal counterparts in biofilms. $\mathrm{FBB}, \mathrm{BB}$ and $\mathrm{FB}$ were developed in vitro in a prescribed Biofilm Formation Medium. The biofilm formation was observed under the light microscope. The biofilms were pelletized and Infra-Red spectra were recorded using Fourier Transform Infrared (FTIR) spectroscopy. FTIR analysis clearly showed the presence of Amide I $\left(\sim 1635 \mathrm{~cm}^{-1}\right)$ and II $\left(\sim 1544 \mathrm{~cm}^{-1}\right), \mathrm{C}-\mathrm{O}$ and $\mathrm{P}=\mathrm{O}$ stretching, and $\mathrm{CH} 2$ scissoring in FBB and BB. FB showed only the Amide I band. The absorbance values of above functional groups, cellular polysaccharides, amides and fatty acids gradually increased in the first three days of biofilm maturation and then leveled off. FBB showed higher accumulation of all macro molecules recorded at each sampling time, thus demonstrating its increased metabolic activity compared to BB and FB.
\end{abstract}

Keywords: Biofilms, Fungal-bacterial biofilms, Structural properties, FTIR.

\section{INTRODUCTION}

Biofilms are complex, multicellular communities which are adhered to abiotic or biotic surfaces (O'Toole et al., 2000). They comprise of algal, fungal, bacterial or other microbial cells. These cells produce extracellular polymeric substances (EPS) to provide the structure and protection to the community (Kokare et al., 2008). Biofilms are found in natural, industrial and medical environments (Seneviratne, 2003). Free-living cells may transform into biofilms with time (O'Toole et al., 2000). Genetic and metabolic alterations that occur during the biofilm formation can be exploited for improved effects in biotechnological applications (Seneviratne et al., 2008). The functional properties of microbial biofilms have remarkable applications in environmental settings.
Enhanced gene transfer in biofilm communities is useful in bioremediation (Singh et al., 2006). Microbes attached to particulate soil contaminants and aquatic sediments may help degrade soil-bound contaminants (Seneviratne et al., 2008). Biofilm inoculants, commonly known as Biofilmed Biofertilizers (BFBFs), can be used in improving plant growth and crop yield (Seneviratne, 2003; Seneviratne \& Jayasinghearachchi, 2003; Seneviratne et al., 2009; Seneviratne et al., 2009; Buddhika et al., 2016). Although, FBBs have many applications (Seneviratne et al., 2008), their structural properties and biomolecules that are important in functions have not been studied sufficiently.

With the advancement of spectroscopy, scientists have attempted to study the structural attributes of bacterial biofilm formation using FTIR spectroscopy. However, no studies have been undertaken so far using FTIR to study the modifications of cellular structure of FBs and FBBs. FTIR spectroscopy has the benefit of enabling the rapid, reagent less, non-destructive analysis of complex biological samples, hence facilitating high throughput screening and unbiased measurements (Mapelli et al., 2008; Landgrebe et al., 2010). It is a quick, easy to use and inexpensive method compared to many other techniques, and also considered as an information rich source (Roberts, 2010). The analysis of biofilm structures by FTIR spectroscopy showed that amides and carbohydrates are the key bands to recognize the structural variations of biofilm formation (Nichols, 1985). Complementary information of the biofilm formation can be found in the region between 750 and 1800 $\mathrm{cm}^{-1}$, where vibrations of $\mathrm{C}-\mathrm{H},>\mathrm{CH} 2$ and $-\mathrm{CH} 3$ groups, amides, carbonyl groups and polysaccharides are observed (Ojeda et al., 2008).

The present study focused on characterizing structural attributes and some biomolecules that are important in functioning of the FBBs and their resident microbes in monoculture state using FTIR spectroscopy. 


\section{MATERIALS AND METHODS}

\section{Microbial cultures}

A fungal (Aspergillus sp.) and a bacterial strain (diazotrophic Enterobactor sp.) used to develop a fungal-bacterial biofilm (FBB) to promote the growth of strawberry (Fragaria $x$ ananassa) were used as cultures in this experiment. All strains were isolated from the rhizosphere of cultivated strawberry.

\section{Biofilm formation and monitoring}

FBs, BBs and FBBs were formed in $100 \mathrm{~mL}$ of Biofilm Forming Medium (BFM, a patented formulation) described in the protocols at the Microbial Biotechnology Unit (MBU) of the National Institute of Fundamental Studies (NIFS), Sri Lanka. The BFM medium without microbial strains was used as the control. Three replicates of culture flasks for each type of biofilm and the control were incubated under room temperature $\left(25-28^{\circ} \mathrm{C}\right)$ for six days in a shaker (80 rpm) by following complete randomized design. Morphological characteristics of biofilms were observed under a light microscope after mounting the cultures with lacto phenol cotton blue stain. Observations were taken after $0.25,0.5,1.5,3$ and 6 days from the inoculation of the medium.

\section{Sampling}

Sub samples $(20 \mathrm{~mL})$ of the microbial cultures were collected (nondestructive) from each flask at different time intervals as stated above. Samples were centrifuged (6000 rpm for $20 \mathrm{~min}$; SANYO Harrier 18/80) and the pellets were used to analyze the structural properties of biofilm formation using FTIR spectroscopy. Microbial pellets were vacuum dried (Eyela, VOS-4500, $50{ }^{\circ} \mathrm{C}, 48$ hours) and fed to the Attenuated Total Reflectance (ATR) cell of FTIR spectrophotometer (FTIR, Thermo Nicolet, USA).
The absorbance spectra were recorded within the range of $900-1800 \mathrm{~cm}^{-1}$ at a resolution of $4 \mathrm{~cm}^{-1}$. Each spectrum was produced by 256 scans. Spectra were collected and analyzed by OMINIC $®$ software.

\section{Data analysis}

Baseline of each spectrum was corrected by automatic base line correction function. Peak absorbance of functional groups was visualized in amide $\left(1500-1800 \mathrm{~cm}^{-1}\right)$, fatty acid $\left(1400-1500 \mathrm{~cm}^{-1}\right)$ and polysaccharide $\left(900-1200 \mathrm{~cm}^{-1}\right)$ windows in spectra (Naumann et al., 1982). Differences in peak absorbance values under each window were analyzed by General Linear Model (GLM). Treatment means were separated by Tukey's simultaneous mean separation test. Statistical analysis was performed in Minitab ${ }^{\circledR}$ 16.2.1, 2010 .

\section{RESULTS AND DISCUSSION}

\section{Morphology of biofilms}

In FBBs, the fungal filaments were acted as the surface for bacterial cells to colonize (Figure 1a, b, c). Similar observations of FBBs were also noted in previous studies (Bandara et al., 2005; Jayasinghearachchi \& Seneviratne. 2006; Herath et al., 2013). The attachment of bacterial cells to fungal filaments was initiated within the first 6 hours of biofilm formation (Figure 1a). The highest number of bacterial cell attachments in FBB was observed after 12 hours (Figure 1b). Further, the detachment and reattachment of bacterial cells were also observed during the course of incubation. The accumulation of extracellular polymeric substances (EPS) was clearly observed during the maturation of FBB. The highest accumulation of EPS was observed in 1.5 days old FBB (Figure 1c). BB depicted EPS accumulation by enlarging cells over time. However,
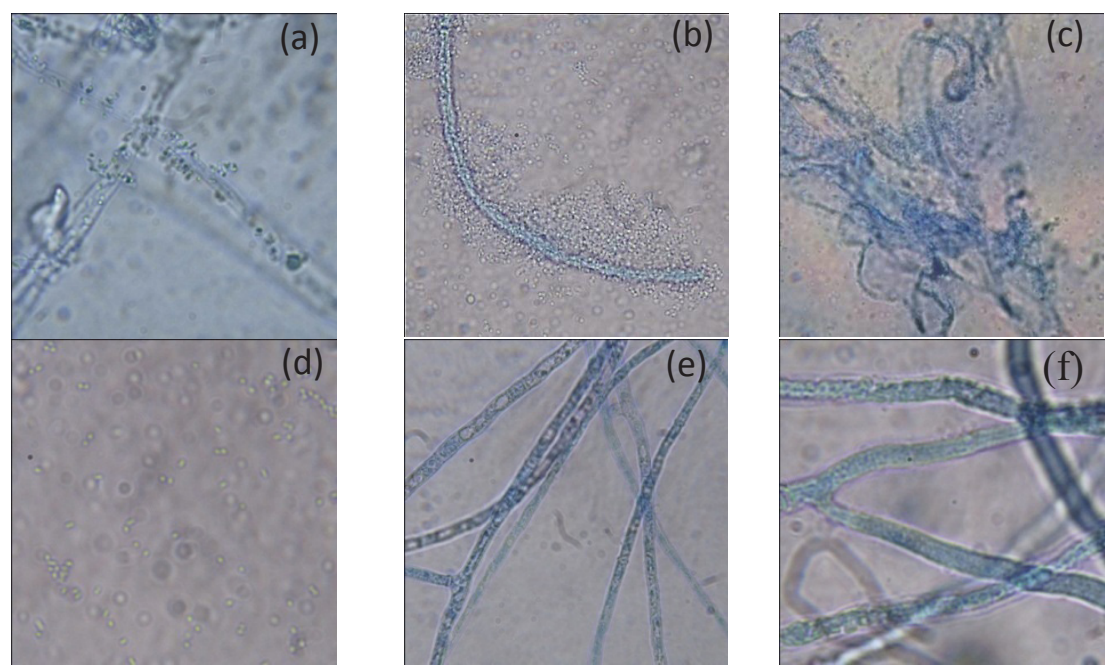

Figure 1: Morphological characteristics of fungal (FB), bacterial (BB) and fungal-bacterial biofilms (FBBs). (a) initiation of bacterial cell attachment with fungal filament after 6 hours of inoculation (b) well developed FBB after 12 hours, (c) Maximum accumulation of extracellular polymeric substances (EPS) after 1.5 days (d) aggregation of bacterial cells in 3 days old BB, (e) colourless spaces in FB after 1.5 days (f) degradation of walls of fungal filaments after 6 days. 
the BBs did not show any characteristic shapes observed on abiotic surfaces (e.g. conical or mushroom) as noted in previous studies (Costerton et al., 1995). Thus, the BB in the present study can be classified as a biofilm formed by cells attaching with each other, providing biotic surfaces to the formation of the biofilm. Cell aggregation was observed on the $3^{\text {rd }}$ day of the BB maturation (Figure 1d). Architectural models of FBs have been studied in detail of clinically important microbe, Candida albicans (Fanning \& Mitchell, 2012). Presence of extracellular matrix (ECM) makes the structural heterogeneity and metabolic diversity among FBs (Fanning \& Mitchell, 2012). In the present study, the density of fungal filaments increased with time. Mucilaginous appearance was noted in 3 and 6 days old biofilms. In addition, colorless spaces were observed in 1.5days old fungal filaments (Figure 1e) and the degradation of filament walls was observed once the FB reached its $6^{\text {th }}$ day of development (Figure 1f).

\section{Characterization of structural attributes during biofilm formation}

FTIR spectra of FBB, BB and FB are shown in Figure 2. Formation of $\mathrm{FBBs}$ and $\mathrm{BB}$ produced common absorption bands at 1234, 1402, 1455, 1544 and $1635 \mathrm{~cm}^{-}$ ${ }^{1}$. The FBB produced two unique bands at 1057 and $1077 \mathrm{~cm}^{-1}$. BB produced one unique band at $1060 \mathrm{~cm}^{-1}$. Tentative assignment of the bands corresponding to above absorbance frequencies are given in Table 1. In our study, amide I and II bands were prominent in FBB and BB, as they are characteristic features of many bacterial strains (Naumann et al., 1982). The IR spectra recorded for BB and FBB were comparable to that of some Caulobacter spp. biofilms, because proteins of Caulobacter spp. cell internal organization are co-conserved across many diazotrophs (Nivens et al., 1993; McAdams and Shapiro, 2011).

The initial growth of FB was rather slow. Thus, it was hard to capture IR spectra for immature FB. The first spectrum of the FB was captured when it was 3 days old and it visualized two peaks for Amide I band $\left(\sim 1635 \mathrm{~cm}^{-1}\right)$ and $\mathrm{P}-\mathrm{O}$ and $\mathrm{C}-\mathrm{O}$ bond stretching $\left(\sim 1080 \mathrm{~cm}^{-1}\right)$. Amide II band was not observed in the FB during the study period (Figure 2c).

The changes of IR band intensities of the biofilms over time are given in Figures $3 \mathrm{a}-\mathrm{f}$. Except the $\mathrm{P}-\mathrm{O}$ and $\mathrm{C}-\mathrm{O}$ stretching, the intensities of all the other bands significantly increased in the FBB with time. A similar observation was also noted with the BB. The intensities of $\mathrm{P}-\mathrm{O}$ and $\mathrm{C}-\mathrm{O}$ stretching and Amide I bands showed no significant change with the maturation of the FB. Generally, in all biofilms, band intensities increased within the first 3 days, and then started to stabilize gradually. Caulobacter sp. biofilm also showed a similar trend during the first 3 days of maturation, before leveling off gradually (Nivens et al., 1993), possibly due to the cellular similarities mentioned above.

The window-wise data of FTIR spectra were used to explain the concentrations of polysaccharides, amides and fatty acids of biofilms. Structural polysaccharides significantly increased during the formation of $\mathrm{FBB}$ (Figure 4a). However, in BB and FBB, polysaccharide concentration did not significantly change with time (Figure $4 a)$. The highest average concentration of polysaccharides was observed in 3-day old FBB (Figure 6a). The concentrations of amides present in biofilms are given in figure $4 \mathrm{~b}$. The concentrations of amide based compounds increased significantly in FBB over time. However, in BB, the concentrations of amide based compounds significantly decreased from 0.5 day to 1.5 days followed by an increase. Amide concentration of FB did not change with time. Fatty acid concentration of FBB significantly increased from 0.5 day to 3 day, and then was maintained at a static level (Figure 4c). Cellular fatty acid concentration of the BB did not significantly change with time (Figure 4c). However, fatty acid concentration of FBB was higher in all sampling times than that of the BB and FB (Figure 4c). The FB did not express absorbance bands in fatty acid window during the study period.

Table 1: Assignment of the main bands of IR spectra recorded in the study and their respective references.

\begin{tabular}{|c|c|c|}
\hline Band frequency $\left(\mathrm{cm}^{-1}\right)$ & Band assignment & References \\
\hline$\sim 1057$ & Carbonyl and alcoholic groups & (Suresh , 2012) \\
\hline$\sim 1060$ & $\mathrm{C}-\mathrm{O}$ stretching and $\mathrm{C}-\mathrm{O}$ deformation & (Yang et al., 2007) \\
\hline$\sim 1077$ & C-O stretching in carbohydrate & (Zhao et al., 2006) \\
\hline$\sim 1080$ & $\mathrm{P}-\mathrm{O}$ and $\mathrm{C}-\mathrm{O}$ stretching & (Nivens et al., 1993) \\
\hline$\sim 1234(\sim 1235)$ & $\mathrm{P}=\mathrm{O}$ stretch & (Nivens et al., 1993) \\
\hline$\sim 1402$ & $\mathrm{C}=\mathrm{O}$ symmetric stretching of $\mathrm{COO}^{-}$ & (Erukhimovitch et al., 2005) \\
\hline$\sim 1455$ & Alkanes, alicyclic $\mathrm{CH} 2$ scissor & (Mistry, 2009) \\
\hline$\sim 1544$ & $\begin{array}{l}\text { Amide II, N-H bending, } \mathrm{C}-\mathrm{N} \text { stretch of } \\
\text { proteins and peptides }\end{array}$ & (Muyonga et al., 2004) \\
\hline$\sim 1635$ & $\begin{array}{l}\text { Amide } \mathrm{I},>\mathrm{C}=\mathrm{O} \text { stretch and } \mathrm{C}-\mathrm{N} \text { bending of } \\
\text { protein and peptides amide }\end{array}$ & $\begin{array}{l}\text { (Naumann et al., 1982; Nivens et al., } \\
\text { 1993; Bosch et al., 2006) }\end{array}$ \\
\hline
\end{tabular}


(a)

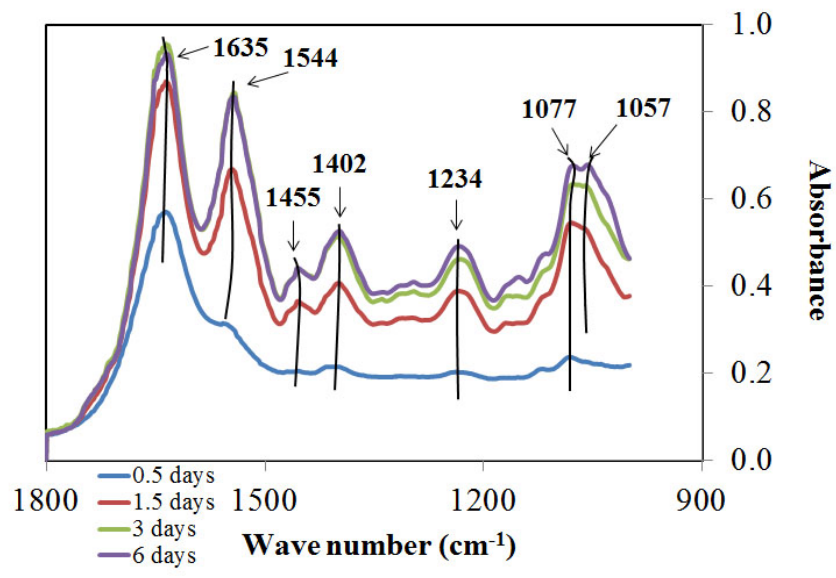

(b)

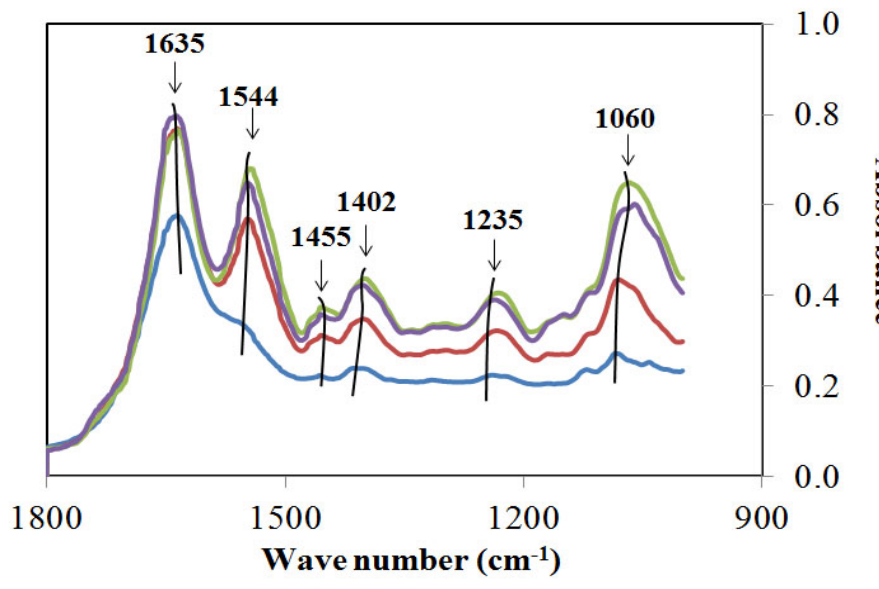

(c)

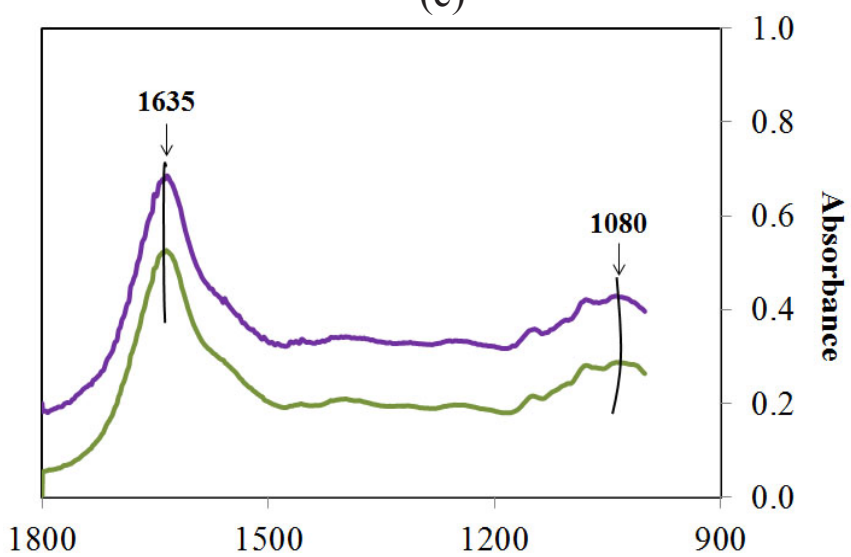

Wave number $\left(\mathrm{cm}^{-1}\right)$

Figure 2: Comparison of the FTIR spectra (1800 - $\left.900 \mathrm{~cm}^{-1}\right)$ of (a) fungal-bacterial (FBB), (b) bacterial (BB) and (c) fungal biofilm (FB) under four maturation stages, $0.5,1.5,3$ and 6 days. The spectra have been vertically displaced to enhance the clarity. 
(a)

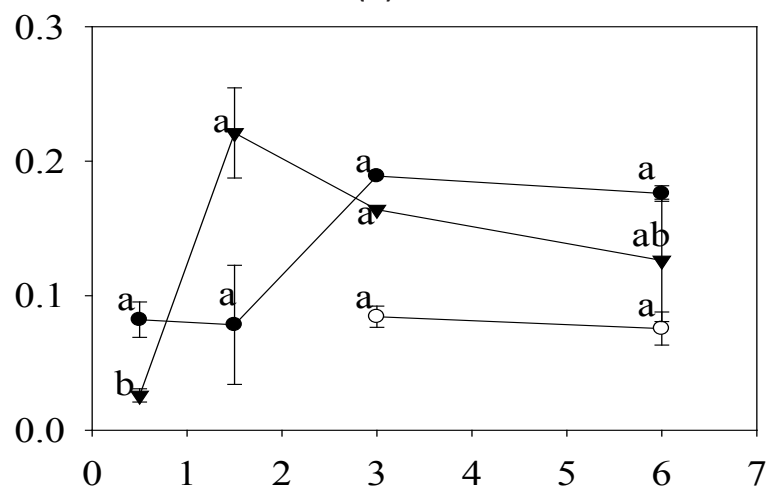

(c)



(e)

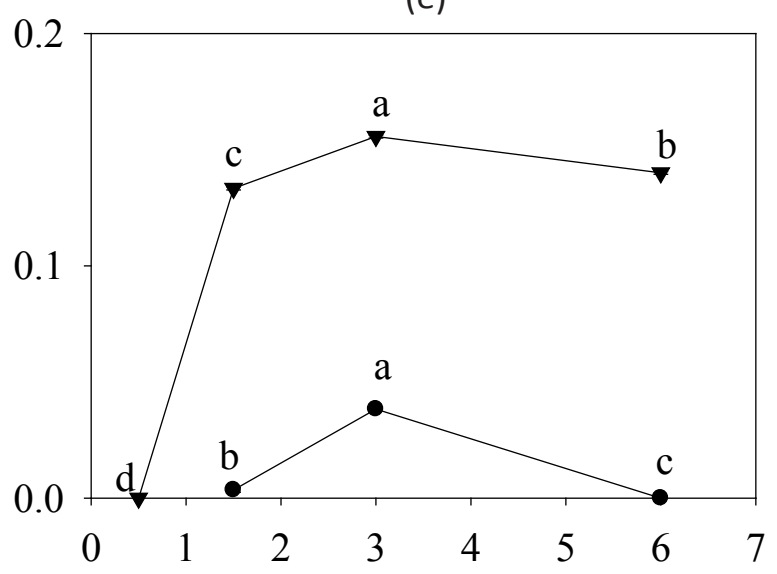

(b)

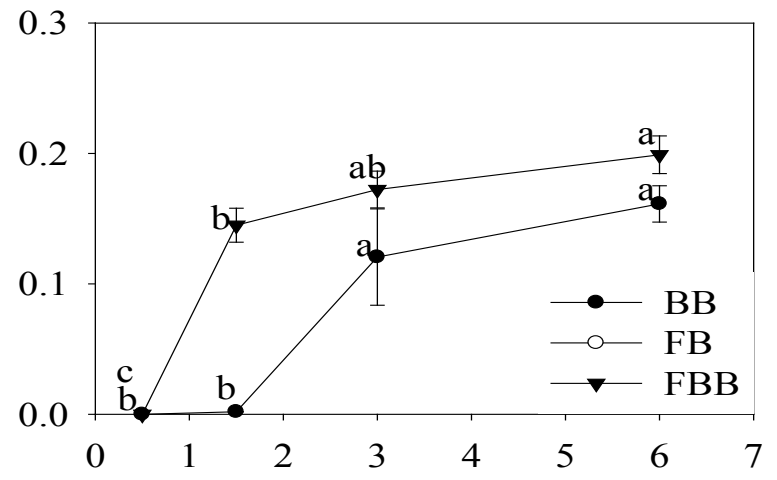

(d)

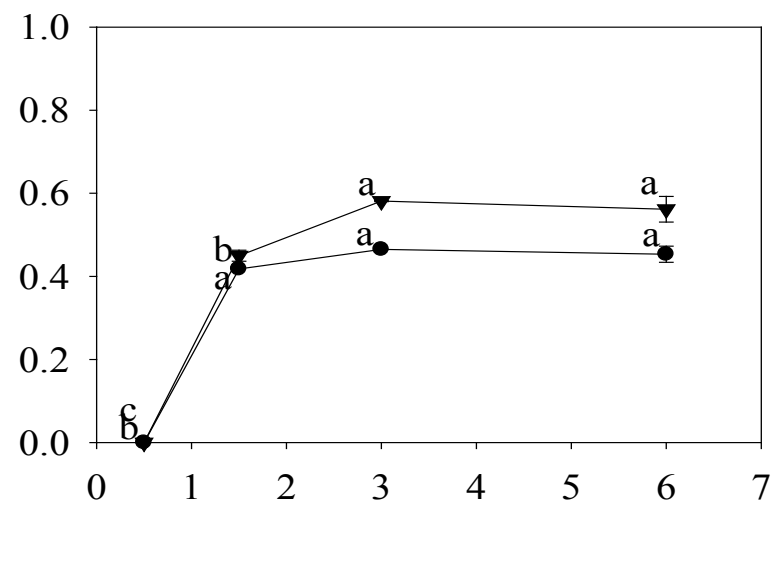

(f)

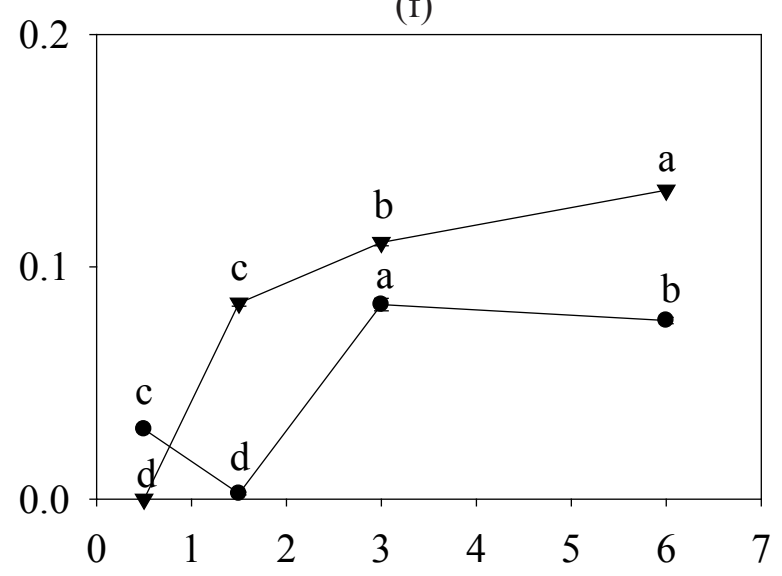

Time (Days)

Figure 3: Change in concentration as reflected from absorbance of (a) P-O and C-O stretching, (b) C-O stretch in carboxylate ion, (c) Amide I band, (d) Amide II band, (e) $\mathrm{CH}_{2}$ scissoring and (f) $\mathrm{P}=\mathrm{O}$ stretch of fungal-bacterial (FBB), bacterial (BB) and (c) fungal biofilm (FB) with the maturation. Concentrations with the same letter along a line of the same interaction are not significantly different at $5 \%$ probability level. 
(a)

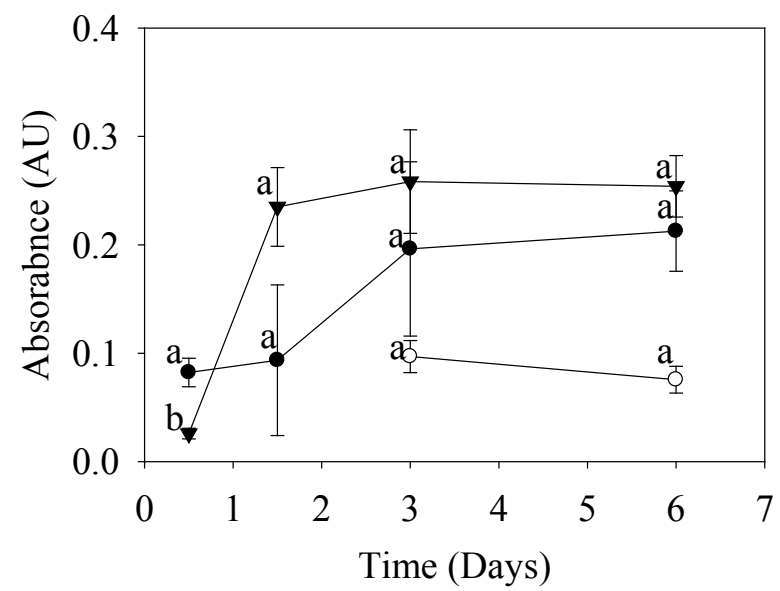

(b)

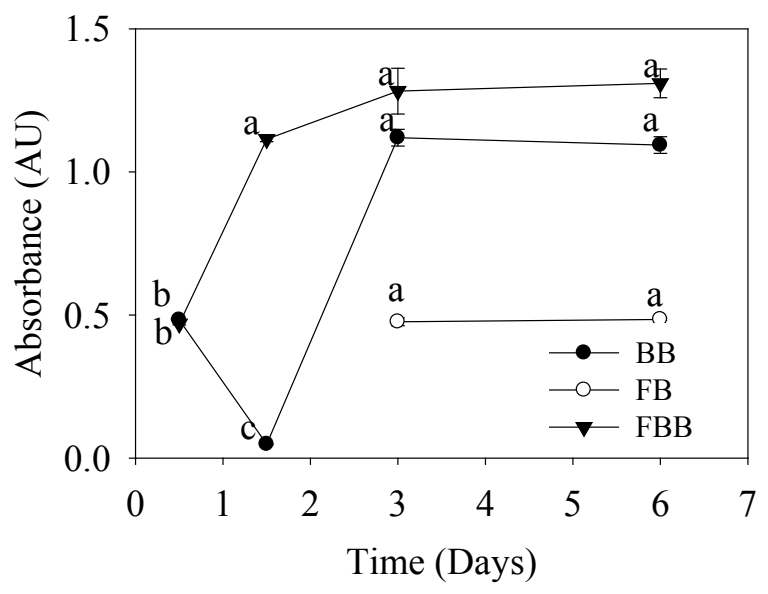

(c)

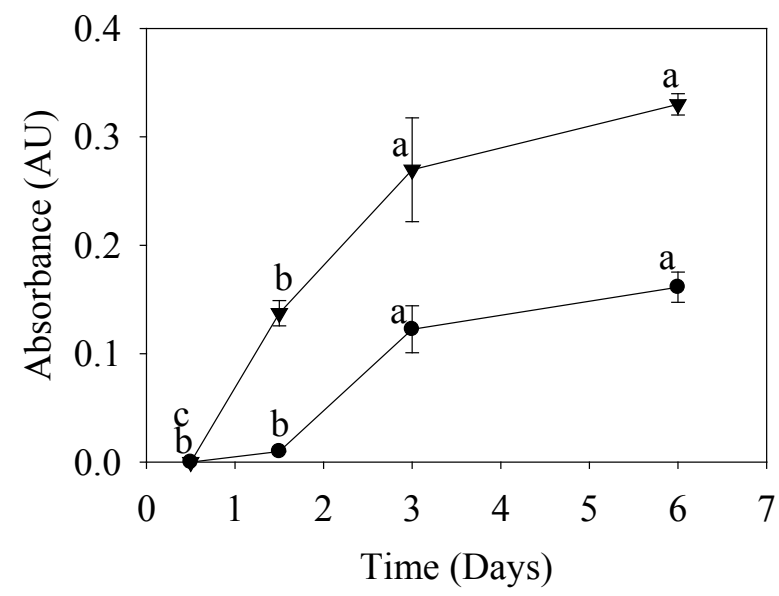

Figure 4: Changes in concentrations of polysaccharides (a), amides (b) and fatty acids (c) of fungal-bacterial (FBB), bacterial (BB) and fungal biofilm (FB) with time $0.5,1.5,3$ and 6 days. . Data were gathered from polysaccharide $\left(900-1,200 \mathrm{~cm}^{-1}\right)$, amide $(1,500-$ $\left.1,800 \mathrm{~cm}^{-1}\right)$ and fatty acids $\left(1,400-1,500 \mathrm{~cm}^{-1}\right)$ windows of FTIR spectra. Concentrations with the same letter along a line of the same interaction are not significantly different at $5 \%$ probability level.

\section{CONCLUSIONS}

All three biofilms showed distinct morphological characteristics during their formation. The FBB showed higher morphological heterogeneity during the formation in comparison with the other two biofilms (BB and FB). Cellular polysaccharides, amides and fatty acids drastically increased during the early stages of biofilm formation and maturation before reaching a static phase. A higher accumulation of cellular polysaccharides and amides was observed in the FBB. In conclusion, FTIR spectroscopy can be recommended as a rapid, informative and powerful tool in comparative studies in evaluating structural properties of FBBs, BBs and FBs.

\section{ACKNOWLEDGEMENT}

The study was partially funded by University Grants Commission of Sri Lanka (UGC/ICD/RG/02/2012/10). We acknowledge Mr. Anura Pathirana, Chief Technical Officer of the National Institute of Fundamental Studies for his excellent technical assistance.

\section{REFERENCES}

Bandara, W.M.M.S., Seneviratne, G., Kulasooriya, S.A. (2006). Interactions among endophytic bacteria and fungi: effects and potentials. Journal of Bioscience 31:645-650.

Bosch, A., Serra, D., Prieto, C., Schmitt, J., Naumann, D., Yantorno, O. (2006). Characterization of Bordetella pertussis growing as biofilm by chemical analysis 
and FT-IR spectroscopy. Applied Microbiology and Biotechnology 71: 736-747.

Buddhika, U.V.A., Seneviratne, G., Ekanayake, E.M.H.G.S., Senanayake, D.M.N., A.D. Igalavithane, A.D., Weeraratne , N., Jayasekara, A.P.D.A., Weerakoon, W.L., Indrajith, A., Gunaratne, H.M.A.C.,. Kumara, R.K.G.K, De Silva, M.D.S.L., Kennedy, I.R. (2016). Biofilmed biofertilizers application in agroecosystems. in: V.K. Gupta, D. Thangdurai, G.D. Sharma (eds.), Microbial Bioresources, CAB International, Wallingford, United Kingdom. 96-106.

Costerton, J.W., Lewandowsk, Z., Caldwell, D.E., Korber, D.R., Lappin-Scott, H.M. (1995). Microbial biofilms. Annual Reviews of Microbiology 49: 711-745.

Erukhimovitch, V., Tsror, L., Hazanovsky, M., Talyshinsky, M., Mukmanov, I., Souprun, Y., Huleihel, M. (2005). Identification of fungal phyto-pathogens by Fouriertransform infrared (FTIR) microscopy. Journal of Agricultural Science and Technology 1: 145-152.

Fanning, S., Mitchell, A.P. (2012). Fungal biofilms. PLOS Pathogens. 8: e1002585.

Herath, H.M.L.I., Senanayeke, D.M.N., Seneviratne, G., Bandara, D.C. (2013). Variation of biochemical expressions of developed fungal-bacterial biofilms over their monocultures and its effect on plant growth. Tropical Agricultural Research 24: 186-192.

Jayasinghearachchi, H.S., Seneviratne, G. (2006). A mushroom-fungus helps improve endophytic colonization of tomato by Pseudomonas flurescens through biofilm formation. Research Journal of Microbiology 5: 83- 89.

Kokare, C.R., Chakraborthy, S., Khopade, A.N., Mahadik, K.R. (2008). Biofilms: Importance and applications. Indian Journal of Biotechnology 8: 159-168.

Landgrebe, D., Haake, C., Höpfner, T., Beutel, S., Hitzmann, B., Scheper, T., Rhiel, M., Reardon, K.F. (2010). Infrared spectroscopy for bioprocess monitoring. Applied Microbiology and Biotechnology 88:11-22.

Mapelli, V., Olsson, L., Nielsen, J. (2008). Metabolic foot printing in microbiology: methods and applications in functional genomics and biotechnology, Cell 26: 490497.

McAdams, H.H., Shapiro, L. (2011). The architecture and conservation pattern of whole cell control circuitry. Journal of Molecular Biology 409: 28-35.

Mistry, B.D. (2009). A Handbook of Spectroscopic Data - Chemistry (UV, IR, NMR, ${ }^{13}$ CNMR and Mass Spectroscopy). Oxford Book Company, Jaipur, India.

Muyonga, J.H., Cole, C.G.B., Duodu, K.G. (2004). Fourier transform infrared (FTIR) spectroscopic study of acid soluble collagen and gelatin from skins and bones of young and adult Nile perch (Latesniloticus). Food Chemistry 86: 325-332.

Naumann, D., Barnickel, G., Bradaczek, H., Labischinski, H., Giesbrecht, P. (1982). Infrared spectroscopy, a tool for probing bacterial peptidoglycan potentialities of infrared spectroscopy for cell wall analytical studies and rejection of models based on crystalline chitin. European Journal of Biochemistry 125:505-515.

Nichols, P.D., Henson, J.M., Guckert, J.B., Nivens,
D.E., White, D.C. (1985). Fourier transform-infrared spectroscopic methods for microbial ecology: analysis of bacteria, bacteria polymer mixtures and biofilms. Journal of Microbiological Methods 4: 79-94.

Nivens, D.E., Chambers, J.Q., Anderson, T.R. (1993). Monitoring microbial adhesion and biofilm formation by attenuated total reflection/Fourier transform infrared spectroscopy. Journal of Microbiological Methods 17: 199-213.

O’Toole, G., Kaplan, H.B., Kolter, R. (2000). Biofilm formation as microbial development. Annual Review of Microbiology 54: 49-79.

Ojeda, J.J., Romero-Gonzalez, M.E., Pouranand, H.M., Banwart, S.A. (2008). In situ monitoring of the biofilm formation of Pseudomonas putida on hematite using flow-cell ATR-FTIR spectroscopy to investigate the formation of inner-sphere bonds between the bacteria and the mineral. Mineralogical Magazine 72: 101-106.

Roberts, R. (2010). The in situ function of a microbial community profiled by FT-IR: a snapshot in time, M.Sc. thesis. University of Nebraska, USA.

Seneviratne, G. (2003). Development of eco-friendly, beneficial microbial biofilms. Current Science 85: 1395-1396.

Seneviratne, G., Jayasinghearachchi, H.S. (2003). Mycilial colonization by bradyrhizobia and azorhizobia. Journal of Bioscience 28: 243-247.

Seneviratne, G., Kecske's, M.L., Kennedy, I.R. (2008). Biofilmed biofertilisers: novel inoculants for efficient nutrient use in plants. In: I.R. Kennedy, A.T.M.A. Choudhury, M.L. Kecske's, and M.T. Rose (Eds), Efficient nutrient use in rice production in Vietnam achieved using inoculants biofertilisers, ACIAR Proceeding No. 130, ACIAR, Canberra, 12-13.

Seneviratne, G., Pevvast, G.A., Olfati, J.A., Kariminia, A. (2009). Rhizobia as biofertilizers for mushroom cultivation. Current Science 96:1559.

Seneviratne, G., Weerasekara, M.L.M.A.W., Zavahir, J.S. (2010). Microbial biofilms: how effective in rhizobiumlegume symbiosis? In: M.S. Khan et al. (eds), Microbes for Legume Improvement, Springer-Verlag. 123-136.

Singh, R., Paul, D., Jain, R.K. (2006). Biofilms: implications in bioremediation. Trends in Microbiology 14:389 -397.

Suresh, K.A. (2012). Metalic nanocrystallites and their interaction with microbial systems, Springer.

Yang, H., Yan, R., Chen, H., Lee, D.H., Zheng, C. (2007). Characteristics of hemicellulose, cellulose and lignin pyrolysis. Fuel 86: 1781-1788.

Zhao, D., Liu G., Song, D., Liu, J., Zhou, Y., Ou, J., Sun, S. (2006). Fourier transform infrared spectroscopic study of truffles. Proceedings of SPIE 6026: 60260H-1$60260 \mathrm{H}-7$. 